Thorax 1987;42:909-910

\title{
Tumour induced hypophosphataemia associated with small cell carcinoma of the bronchus
}

\author{
J BANKS, M D PENNEY, E G ANDERSON \\ From Newport Chest Clinic, St Woolos Hospital, Gwent, and the Department of Chemical Pathology, Royal \\ Gwent Hospital, Newport
}

We report a paraneoplastic syndrome complicating small cell bronchogenic carcinoma, characterised by a proximal renal tubular defect, renal phosphate wasting, hypophosphataemia, aminoaciduria, glycosuria, and diffuse bone pain.

\section{Case report}

A 37 year old man gave a two month history of mild dysphagia, weight loss, haemoptyses, and pain affecting the lumbar spine, buttocks, and thighs. He had been previously well with no relevant past medical history. There were no abnormal physical findings. A barium meal showed nothing abnormal but the chest radiograph showed a left hilar mass and bronchoscopy revealed neoplastic occlusion of the left upper lobe bronchus. Bronchial biopsy specimens confirmed small cell carcinoma.

Investigations showed that the serum phosphate concentration was 0.5 (normal $0.8-1.5$ ) mmot/l (1.5 (2.5-4.6) $\mathrm{mg} / 100 \mathrm{ml})$, serum calcium $2.6 \mathrm{mmol} / 1(10.4 \mathrm{mg} / 100 \mathrm{ml})$ (corrected for the low serum albumin), and alkaline phosphatase $170 \mathrm{U} / 1$ (figure). His full blood count and urea, creatinine, and electrolyte concentrations were normal. He had persistent $2 \%$ glycosuria despite normal blood sugar concentrations. Aspartate transaminase activity was 90 (normal $0-35$ ) $U / 1$ and $\gamma$ glutamyl transaminase activity 217 (normal 0-50) U/l. Alkaline phosphatase isoenzymes showed an increase in the bone fraction. Radiographs of the spine and pelvis were normal.

He was initially treated with vincristine, adriamycin, cyclophosphamide, and etoposide and the same drug regimen was repeated three weeks later (figure). There was no radiographic improvement and he developed increasingly severe back pain, which now prevented him from standing. Examination showed considerable paraspinal muscle spasm and generalised skin and palmar crease hyperpigmentation. Serum cortisol concentrations at 09.00 and 24.00 hours were 583 (normal 138-690) nmol/l (21 (5-25) $\mu \mathrm{g} / 100 \mathrm{ml})$ and 607 (normal 96-330) nmol/l (22 (3.5-12) $\mu \mathrm{g} / 100 \mathrm{ml}$ ) respectively, urinary free cortisol 1330 (normal 96-330) nmol $24 \mathrm{~h}$ $(48(3 \cdot 5-12) \mu \mathrm{g} / 24 \mathrm{~h})$; but the serum adrenocorticotrophic hormone $(\mathrm{ACTH})$ concentration was 58 (normal $<10-80$ )

Address for correspondence: Dr J Banks, Newport Chest Clinic, 129 Stow Hill, Newport, Gwent NP9 4GA.

Accepted 9 January 1987 $\mathrm{ng} / \mathrm{l}$ and the serum potassium concentration remained within the normal range. Serum sodium concentration fell to 113 (normal 136-148) $\mathrm{mmol}(\mathrm{mEq}) / 1$, serum osmolality was 246 (normal 275-295) mmol(mosm)kg, and urine osmolality $742 \mathrm{mmol} / \mathrm{kg}$. The plasma arginine vasopressin concentration was $73.3 \mathrm{pg} / \mathrm{ml}$ (with hypo-osmolality the physiological range should be less than the detection limit of 0.25 $\mathrm{pg} / \mathrm{ml}$ ). Parathormone concentrations were normal, and a bone scan was normal.

It was thought that his pain might be due to extradural metastatic disease but irradiation of the spine and chest failed to alleviate his symptoms and did not alter the chest radiograph. Despite severe and persistent hypophosphataemia, renal tubular reabsorption of phosphate (TmP/GFR) was very low (figure), and urinary chromatography showed excessive excretion of the amino acids threonine, serine, glycine, cystine, tyrosine, and lysine. Serum osmolality remained low $(217 \mathrm{mmol} / \mathrm{kg})$, with a grossly raised serum arginine vasopressin concentration (112 $\mathrm{pg} / \mathrm{ml}$ ), which failed to respond to fluid restriction (750 $\mathrm{ml} /$ day). Demeclocycline was given in the terminal stages but failed to correct the hyponatraemia. He deteriorated and died three months after presentation.

\section{Discussion}

Small cell carcinoma in this patient was complicated by the development of two definite paraneoplastic syndromestumour induced hypophosphataemia, which was the probable cause of his pain, and inappropriate antidiuretic hormone secretion. In addition, his skin hyperpigmentation and high cortisol concentrations raised the possibility of the ectopic ACTH syndrome, but this was not unequivocally established since he never developed hypokalaemia and the only measurement made of the serum ACTH concentration was normal. Alternatively, the raised cortisol concentrations could have been stress induced.

Tumour induced hypophosphataemia is a rare condition most frequently described with benign mesenchymal neoplasms of bone ${ }^{1}$ and more recently with prostatic carcinoma. ${ }^{2}$ Characteristically, as in this case, the mechanism leading to hypophosphataemia is impairment of proximal renal tubular reabsorption of phosphate, characterised by a low TmP/GFR. ${ }^{134}$ Aminoaciduria and glycosuria occur but not invariably. ${ }^{13}$ Serum calcium concentrations are normal but serum alkaline phosphatase activity is raised and reduced concentrations of $1 \alpha$-dihydroxycholecalciferol 

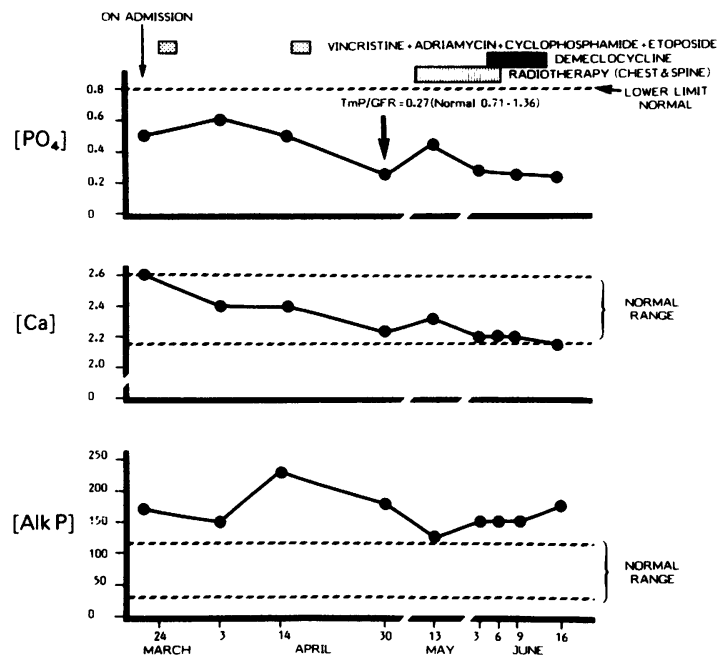

Changes in serum phosphate, calcium, and alkaline phosphatase and treatment received during a three month period. [ $\mathrm{PO}_{4}$ ]-serum phosphate (mmol/l); [Ca]-serum calcium (corrected for albumin; mmolll); [ Alk P]-serum alkaline phosphatase (IU/l); TmP/GFR-renal tubular reabsorption of phosphate.

$\left(1,25(\mathrm{OH})_{2} \mathrm{D}_{3}\right)$ have been reported in some cases. ${ }^{34}$ In the fully established syndrome radiographic changes of osteomalacia appear. ${ }^{1-4}$

Diffuse bone pain and muscle weakness are the usual presenting symptoms ${ }^{1-4}$ and some patients have been misdiagnosed as having ankylosing spondylitis. ${ }^{5}$ When tumour resection has been possible there has been rapid resolution of symptoms and biochemical abnormalities, suggesting that a tumour derived substance is concerned in the pathogenesis. $^{13-6}$ Certain tumours propagated in animals cause reduced serum concentrations of $1,25-(\mathrm{OH})_{2} \mathrm{D}_{3}$ and 25-hydroxycholecalciferol-1-hydroxylase activity in the kidney, ${ }^{6}$ while a saline extractable substance derived from a giant cell tumour rapidly depressed tubular reabsorption of phosphate in mice. ${ }^{7}$ Theoretically, impairment of renal tubular function by a tumour derived factor could simultaneously prevent conversion of 25-hydroxycholecalciferol to $1,25-(\mathrm{OH})_{2} \mathrm{D}_{3}$ since hydroxylation occurs within the mitochondria of the renal tubules. ${ }^{3}$

There are only two previous reports of hypophosphataemia complicating small cell carcinoma of the bronchus. $^{89}$ In both cases hypophosphataemia developed after administration of demeclocycline to treat inappropriate antidiuretic hormone secretion. It was argued that the tubular defect in these cases was probably due to․ demeclocycline induced renal toxicity rather than a para $=$ neoplastic syndrome. ${ }^{9}$ Demeclocycline toxicity could not be implicated in our patient since the drug was only given dur ing the terminal stages.

While there is no direct evidence for a tumour derived $\vec{P}$ phosphaturic factor in our patient the close tempora $ᄃ$ relationship between onset of symptoms, hypo $\omega$ phosphataemia, and tumour diagnosis supports a causa relationship. Furthermore, progressive hypophosphataemiax paralleled worsening of symptoms over a short period and the relatively brief interval from diagnosis to death would account for the absence of radiographic changes of osteo $\vec{F}$ malacia seen in cases associated with more slowly growing mesenchymal tumours. Recognition of this paraneoplastic syndrome as a cause of skeletal pain might have allowed more effective symptomatic treatment. Administration of high doses of vitamin D and phosphate supplements hav been used successfully to treat other patients when tumouf resection has been impossible. ${ }^{1}$

\section{References}

1 Daniels RA, Weisenfeld I. Tumourous phosphaturic osteo malacia. Report of a case associated with multiple hae mangiomas of bone. Am J Med 1979;67:155-9.

2 Lyles KW, Berry WR, Haussler M, Harrelson JM, Drezner MKS Hypophosphataemic osteomalacia: association with prostatio carcinoma. Ann Intern Med 1980;93:275-8.

3 Fukumoto $Y$, Tarui S, Tsukiyama $K$, et al. Tumour-induced vita min D-resistant hypophosphataemic osteomalacia associated with proximal renal tubular dysfunction and $1,25 \vec{F}$ dihydroxyvitamin D deficiency. $J$ Clin Endocr Metab 1979;49:873-8.

4 Drezner MK, Feinglas MN. Osteomalacia due to 1-alpha 25-dihydroxycholecalciferol deficiency. Association with giant cell tumour of bone. J Clin Invest 1977;60:1046-53.

5 Moser CR, Fessel WJ. Rheumatic manifestations of hypoo phosphataemia. Arch Intern Med 1974;134:674-8.

6 Gitelis S, Ryan WG, Rosenberg AG, Templeton AC. Adult onse hypophosphataemic osteomalacia secondary to neoplasm. case report and review of the pathophysiology. J Bone Join? Surg (Am) 1986;68A:134-8.

7 Popovtzer MM. Tumour-induced hypophosphataemic osteo-3 malacia: evidence for a phosphaturic cyclic AMP-independent action of tumour extract. Abstr Clin Res 1981;29:418A.

8 Taylor HC, Fallon MD, Velasco ME. Oncogenic osteomalacia and inappropriate antidiuretic hormone secretion due to oato cell carcinoma. Ann Intern Med 1984;101:786-8.

9 Decaux G, Soupart A, Unger J, Delwiche F. Demeclocycline induced phosphate diabetes in patients with inappropriate secretion of antidiuretic hormone. $N$ Engl J Me\$s 1985;313:1480-1. 